\title{
Fruiting bodies structures of myxomycetes
}

\begin{abstract}
Myxomycetes (plasmodial slime molds) are very important living groups in ecosystem and cosmopolitan species. In this study, morphological structures (Hypothallus, Stalk, Columella, Pseudocolumella, Capillitium, Pseudocapillitium, Peridium, Cortex, Calyculus and Spores) of myxomycetes are given. The structures have supported by the examples shown.
\end{abstract}

Keywords: myxomycetes, plasmodial, mushrooms, yeasts, fungi hyphae, blue-green bacteria, hypothallus, fruiting bodies

\author{
Volume 7 Issue 6 - 2019 \\ Mustafa SEVINDİK, ${ }^{2}$ Hasan AKGÜL' \\ 'Deparment of Biology, Akdeniz University, Turkey \\ 2Deparment of Food Processing, Osmaniye Korkut Ata \\ University, Turkey
}
Correspondence: Hasan AKGÜL, Deparment of Biology, Faculty of Science, Akdeniz University, Turkey, Tel +90 242 3102348 Email hagul@akdeniz.edu.tr

Received: August 07, 2019 | Published: November 27, 2019

\section{Introduction}

Myxomycetes, known as true slime mushrooms or plasmodial slime mushrooms, are multi-nucleated, non-cell walled creatures capable of producing one or more spores. They are fungi-like organisms that are very common in terrestrial ecosystems. They are surrounded by a transparent adhesive scabbard and thin plasma membrane. Plasmodium in the form of a multi-nucleus and acellular protoplasm stack represents the vegetative phase. Plasmodium formation and subsequent haploid chromosome number spores include one or more fructification. Plasmodium is formed by germination of spores. In the sporulation phase, these organisms form a distinctly formed spore mass within the membranous spore sac secreted by the protoplasm. The spore sacs also contain a system of non-cellular, mostly free or reticulated yarns capillitium or pseudocapillitium. Some groups have systematically important characteristic lime deposits inside, outside, or both places in the spore sac..$^{1,2}$ Some species are very common, while others live in certain habitats. Myxomycetes are sensitive to light, moisture and temperature as well as the property of the substrate on which they develop. Mycetozoa members are abundant in cool, damp and shady environments such as decaying stumps, branches, live or dead tree bark, rotten fruit or fruit residues, dead leaves and leaf debris. In addition, some organic materials were collected as exceptional from herbivorous animal feces and rocks. They live in such environments by feeding with other microorganisms (such as bacteria, yeasts, fungi hyphae, blue-green bacteria, and green algae). By collecting materials that may contain spores and plasmodium from the natural environment, sporophore development is provided by the Humidity Chamber Technique in the laboratory. ${ }^{3-7}$ The fruiting bodies of myxomycetes can occur anywhere under optimum conditions (proper humidity, heat and sufficient rotting organic matter). Many myxomycetes species have small fruit stems. It is only a few millimeters in diameter and requires a $20 \times$ lens for fixation ${ }^{8}$. Myxomycetes have four fruiting body forms or types, sporangium, plasmodiocarp, aethalium and pseudoaethalium. The most common fruiting body forms are a stalked sporangium and heterothallic myxomycetes sporangium contains mainly 7 parts.

\section{Hypothallus}

The Hypothallus is a thin layer deposited by plasmodium at the time of fruiting on the surface of the substratum. The hypothallus connects the stalk to the substrate. The hypothallus may be composed of $\mathrm{CaCO}_{3}$, also membranous and transparent. It is relatively thick from the membrane. It can be of different colors, from delicate, hard and transparent to bright. The hypothallus may surround the base of a single fruiting body. And also may form a continuous layer that joins the bases of a plurality of fruiting bodies. The hypothallus may not be apparent at all in some myxomycetes ${ }^{7,9}$ (Figure $1 \& 2$ ).

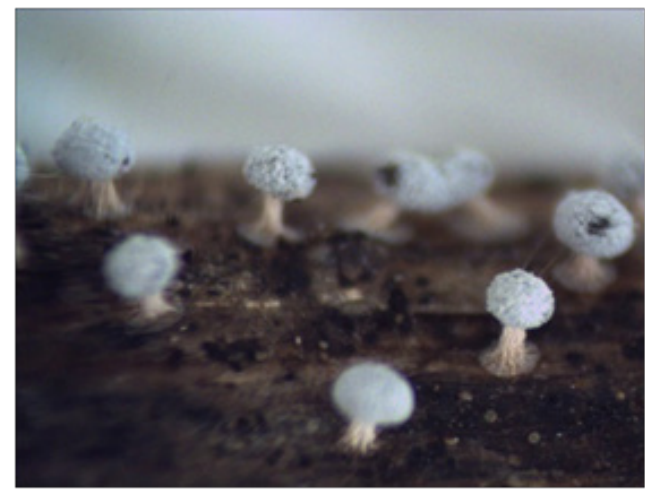

Figure 1 Didymium squamulosum (Alb. \& Schwein.). ${ }^{8}$

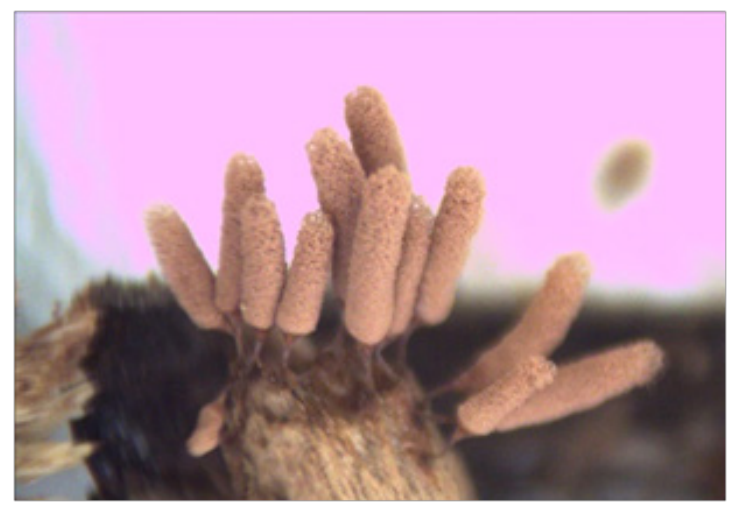

Figure 2 Arcyria denudata (L.). ${ }^{8}$

\section{Stalk}

In certain fruiting bodies, sporangium is elevated above the 
substrate by a stalk (sometimes also called a stipe). The primary function of the stalk is to support and elevate the spores above the substratum. Ayrica protecting the sporangium from excessive moisture and aiding in the dissemination of the dry, powdery spore mass. Stalks display considerable variation in length, thickness, color, and texture. Moreover, they may be hollow or filled with one of several types of material (for example, round, sporelike structures or granular debris), translucent or opaque, and covered with lime or limeless. The stalk may be useful in identifying myxomycetes such as in the Order Physarales where the stalk contains $\mathrm{CaCO}_{3}$ and in the Order Stemonitales where the stalk is either hollow or filled with fibrous strands, or filled with sporelike structures in Arcyria (Figure $3 \& 4) \cdot 7,9,10$

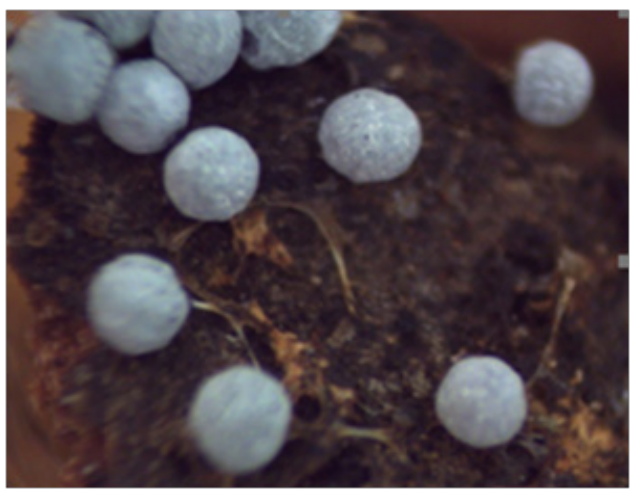

Figure 3 Badhamia dubia Nann.-Bremek.10

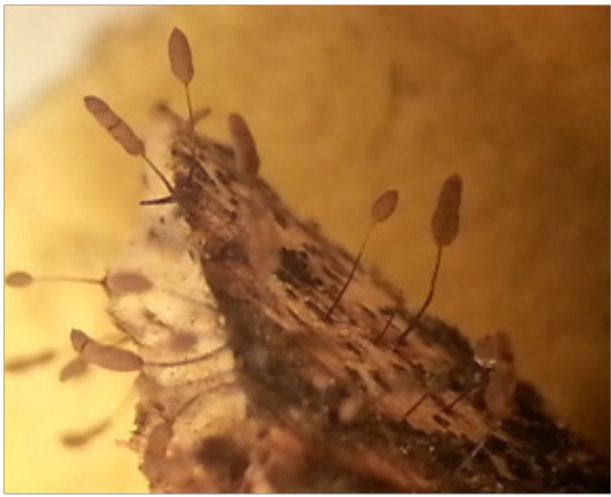

Figure 4 Comatricha tenerrima. ${ }^{10}$

\section{Columella}

In some fruiting bodies, the columella is often an extension of the stalk within the peridium. The columella may be various sizes as dome-shaped, spherical, or elongated central sterile structure within the sporangium. In stalked fruiting bodies, the columella appears to represent an extension of the stalk that simply continues upward into the spore mass, although it may or may not resemble the stalk in structure, shape, texture, and color. In sessile fruiting bodies, the columella ranges from little more than a thickening of the inner side of the peridium where it contacts the substrate to a conspicuous domeshaped structure. Columella may serve as a supporting structure for the capillitium that may be attached in part or throughout its length. Columella may be a short protrusion or extend to the top of the sporangium. Columella is an important part of the definition when it occurs. Used in keys to identify different type ${ }^{11,9}$ This structure is absent in species of the Liceales and Trichiales ${ }^{12}$ (Figure $5 \& 6$ ).

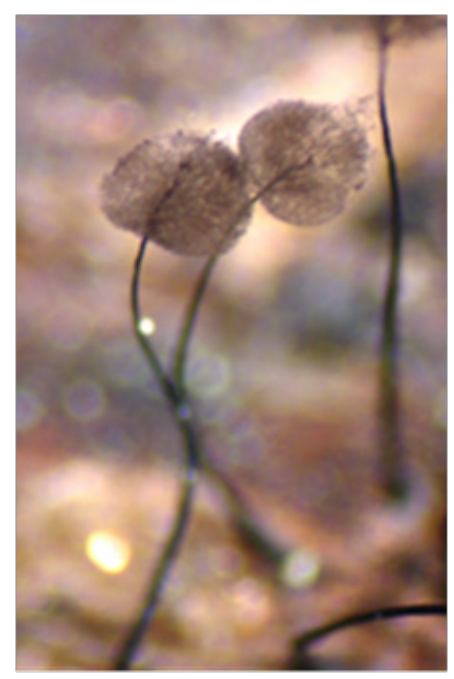

Figure 5 Comatricha nigra (Pers.). ${ }^{12}$

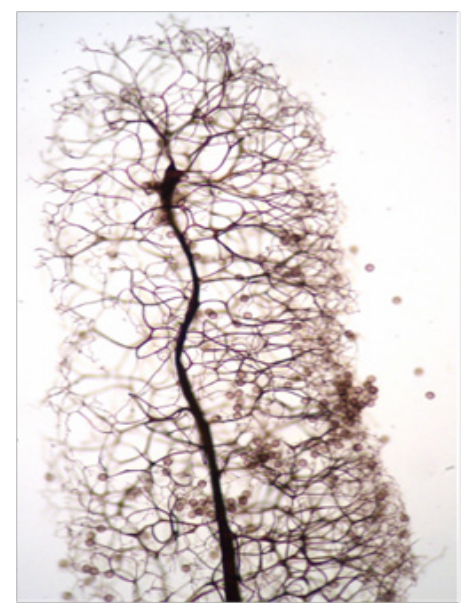

Figure 6 Stemonitis herbatica Peck. ${ }^{12}$

\section{Pseudocolumella}

A pseudocolumella (literally, a false columella) is a structure that resembles a columella. Pseudocolumella does not attach to the stalk. Pseudocolumella is a lime mass freely suspended in the center of the sporangium, resembling a true columella. The lime mass may consist of a single discrete body or may be represented by a loose aggregation of smaller units. ${ }^{79}$ The pseudocolumella is found only in the order Physarales, The example is Craterium leucocephalum Ellis (Figure 7).

\section{Capillitium}

The capillitium (plural: capillitia) is a system of threadlike elements found within the spore mass of the fruiting body in many different species of myxomycetes. Portions of the capillitium may be solid or hollow, free or interconnected, smooth or sculptured. A capillitium containing lime (a badhamioid capillitium) is present only in some members of the Physarales and may be entirely limy or consist of a system of limeless, hyaline tubules connecting conspicuous deposits of lime usually referred to as lime nodes(a physaroid capillitium). These threads form from a system of preformed vacuoles that coalesce, 
giving rise to solid or hollow threads often with debris and of uniform diameter usually less than $6.0 \mu \mathrm{m} .{ }^{7,9}$. Threads in Arcryia species are more or less elastic and expand at maturity ${ }^{13}$ (Figure $8 \& 9$ ).

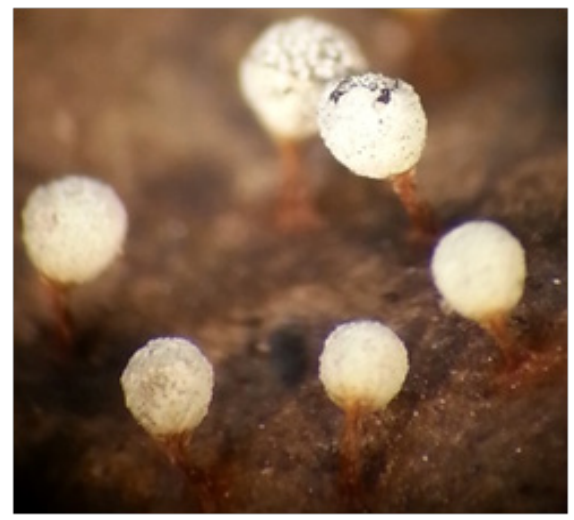

Figure 7 Craterium leucocephalum. ${ }^{13}$

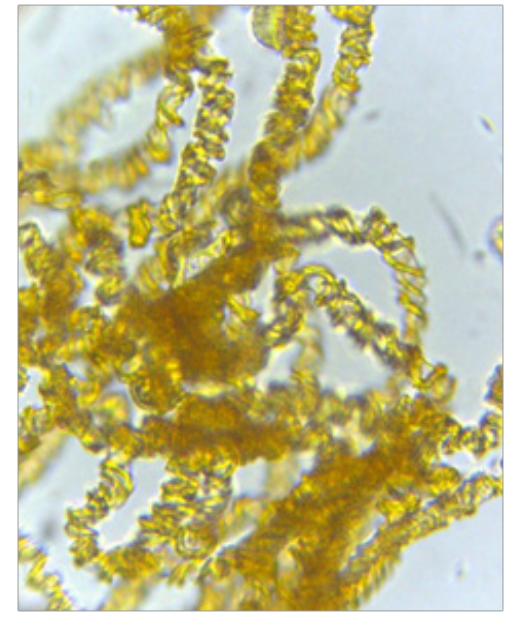

Figure 8 Hemitrichia montana (Morgan) T. Macbr. ${ }^{12}$

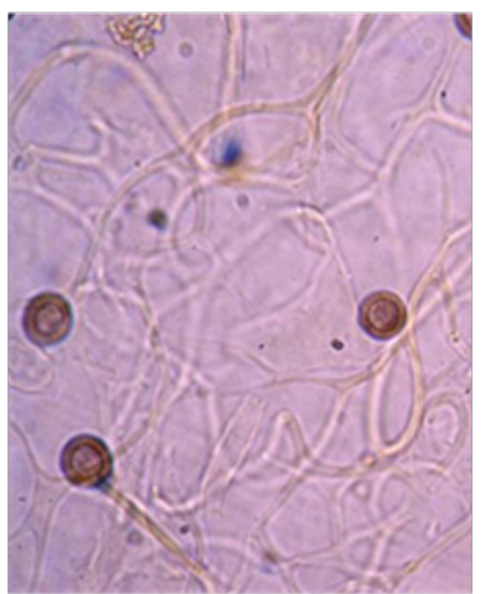

Figure 9 Willkommlangea reticulata (Alb. \& Schwein.) $)^{14}$

\section{Pseudocapillitium}

Pseudocapillitia occur in pseudoaethalia and aethalia those produced by certain members of the Liceales. Unlike the capillitium, where the individual elements are more or less uniform with respect to both overall structure and diameter, the elements making up the pseudocapillitium are distinctly irregular and vary in width or diameter. Pseudocapillitial elements are highly variable in size and shape, and may appear as bristles, threads or perforated plates. Occurring as thread-like, membrane-like, or perforated structures intermingled with the spore mass in Reticularia species. Appears as a system of irregular tubes in aethalia of Lycogala species, such as $L$. epidendrum, where margins are wrinkled and much wider than $6 \mu \mathrm{m}$ in diameter (Figure $10 \& 11$ ) ${ }^{7,9,14}$

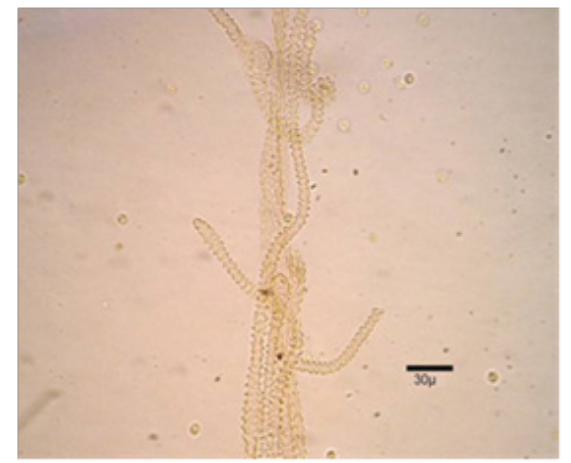

Figure 10 Lycogala epidendrum (J.C. Buxb. ex L.) Fr. ${ }^{15}$

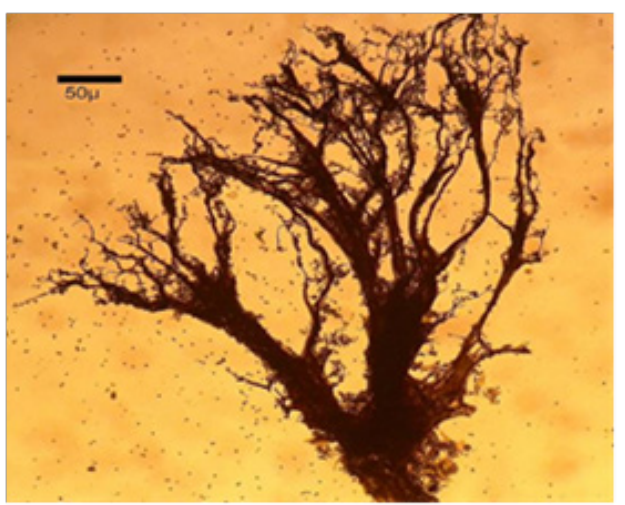

Figure II Amaurochaete atra (Alb. \& Schwein.) Rostaf. ${ }^{14}$

\section{Peridium}

Peridium is that encloses the spores in the endosporous myxomycetes. It varies in structure from delicate, thin, and membranous to relatively tough and thick. In some myxomycetes, the peridium is not evident in mature fruiting bodies. Some peridia are brilliantly colored in hues of orange, yellow, violet, and red. Also others are iridescent or infused with calcium carbonate $\left(\mathrm{CaCO}_{3}\right)$. When maturity, the peridium may be persistent as in Perichaena. Also it may be persistent either single-layered as in P. microspora, double as in P. depressa, or triple as in Physarum bogoriense. ${ }^{7,9}$ Peridium may be membranous and evanescent as in species of Macbrideola or Stemonitis (Figure $12 \& 13$ ). ${ }^{15}$

\section{Cortex}

The rather thick covering that surrounds the spore mass in an aethalium is usually referred to as a Cortex. Cortex is thickened calcareous outer covering of the aethalium in the genus Fuligo. 
This structure appears in all Fuligo species descriptions instead of the term peridium. Because it generally functions in the same way, protecting the black spore mass inside. Fuligo septica (L.) F.H. Wigg is a conspicuous example because of its large size and welldeveloped cortex of calcareous granules. Mucilago crustacea P. Micheli ex F.H. Wigg. also has a thickened cortex. But in this case, it is composed of crystalline not granular calcium carbonate. It is a look-alike species sometimes misidentified as $F$. septica since both are common species found in similar habitats (Figure 14).

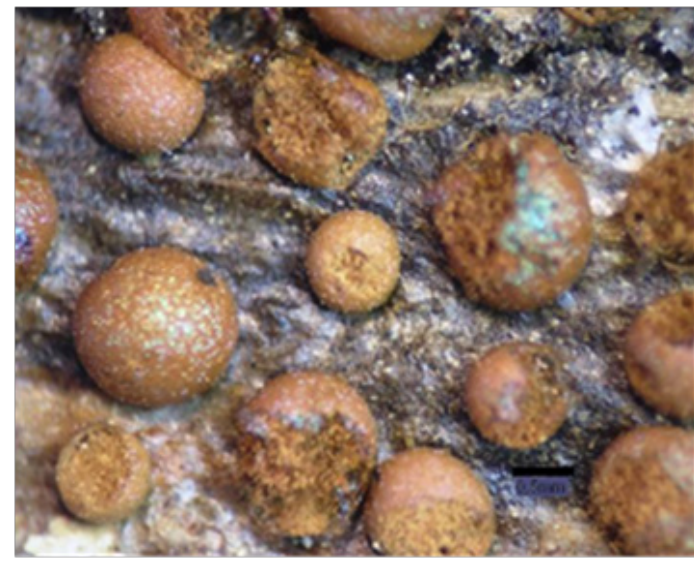

Figure 12 Prototrichia metallica (Berk.) Massee ${ }^{16}$

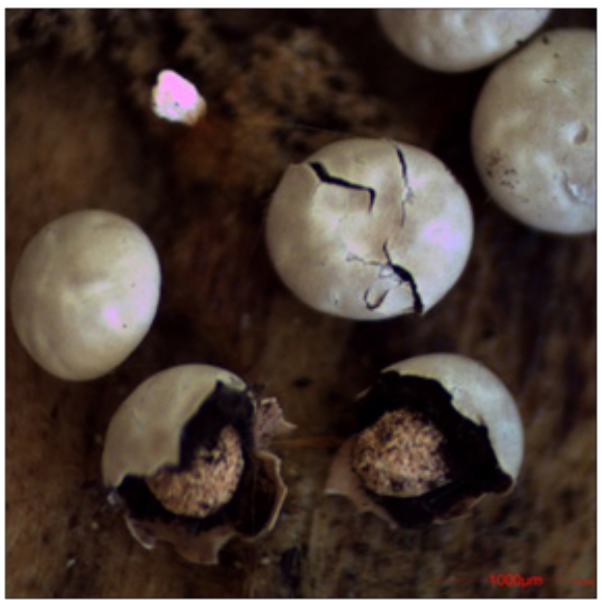

Figure 13 Diderma radiatum (Rostaf.) Morgan ${ }^{10}$
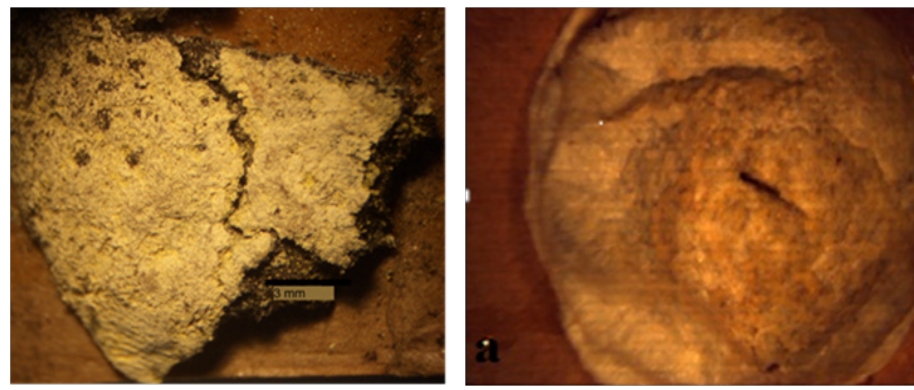

Figure I4 Fuligo septica ${ }^{15}$ Reticularia lycoperdon ${ }^{10}$

\section{Calyculus}

A cup, referring to the persistent peridium forming a cup at the base of a sporangium. Most species in the genera Arcyria and Cribraria have a calyculus. Depth and surface markings on the cup can be used for species identification (Figure $15 \& 16$ ). ${ }^{16}$

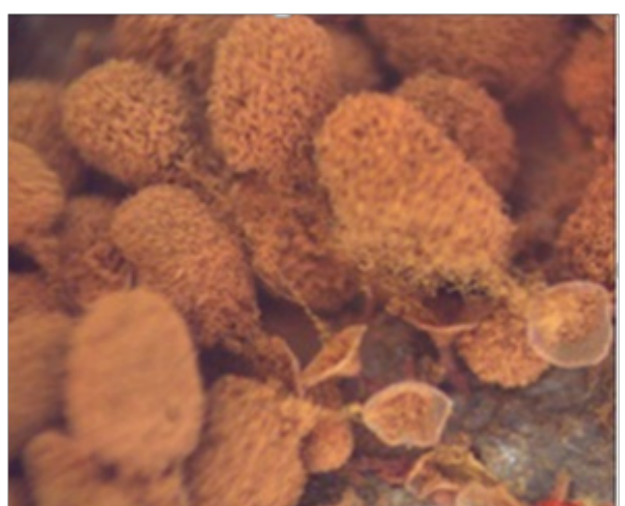

Figure 15 Arcyria minuta Buchet ${ }^{17}$

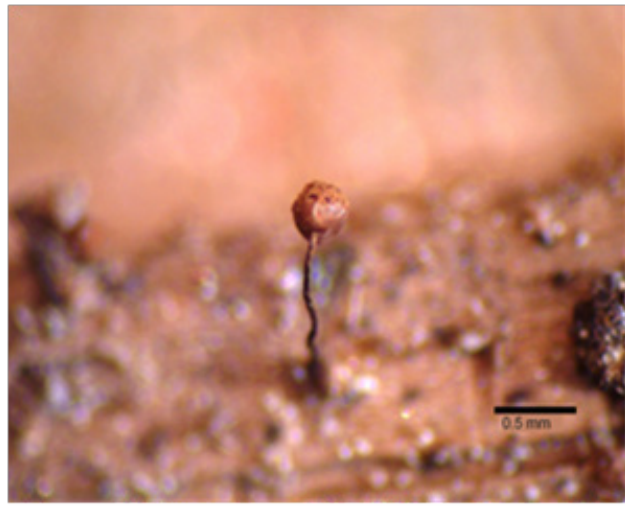

Figure 16 Cribraria piriformis Schrad ${ }^{8}$

\section{Spores}

Spores are the reproductive units, microscopic walled haploid, formed inside the fruiting body. The spores of virtually all myxomycetes are spherical and those of most species have a diameter that falls between 5 and 15 micrometers. In species identification, the color, shape, size and ornamentation of spores can be quite useful. ${ }^{9,10}$ If spore size varies greatly for spores from the same fruiting body, it almost invariably indicates that the fruiting body did not develop normally. Spore color in myxomycetes varies from hyaline to almost black. Also the only colors not found are blue and true green. Spores usually are spherical in shape. Also it is free as single units or aggregated into loose or tight clusters. The various types of ornamentation that can be present on the spores of a particular species include asperulate (roughened or densely but very finely warted), verrucose (with scattered but relatively prominent blunt warts), echinate (with scattered but relatively prominent sharp-pointed spines), and reticulate (covered by a network of ridges). Spores are either dark, as is the case for most members of the Physarales and Stemonitales or pale to brightly colored, which is the condition that exists for all other myxomycetes. Brightly colored spores may be red, yellow, orange, white, pale gray, pink, light or rusty brown. In some species of Badhamia and Dianema corticatum, the spores appear clustered into spore balls (Figure $17 \& 18) .^{9,10,17,18}$ 


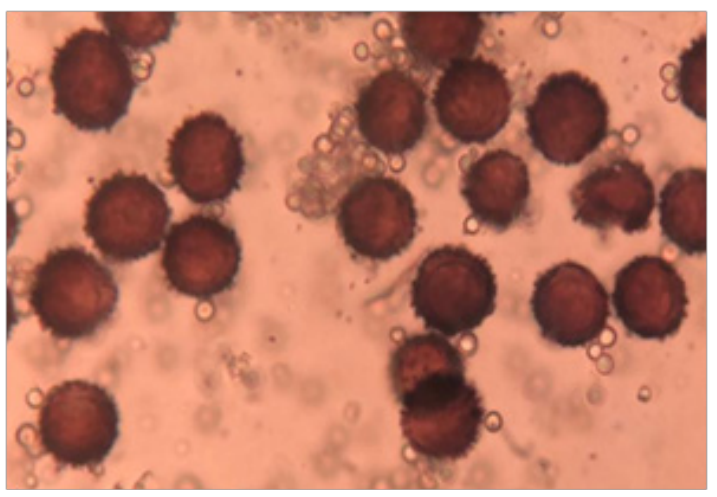

Figure 17 Physarum bitectum G. Lister ${ }^{18}$

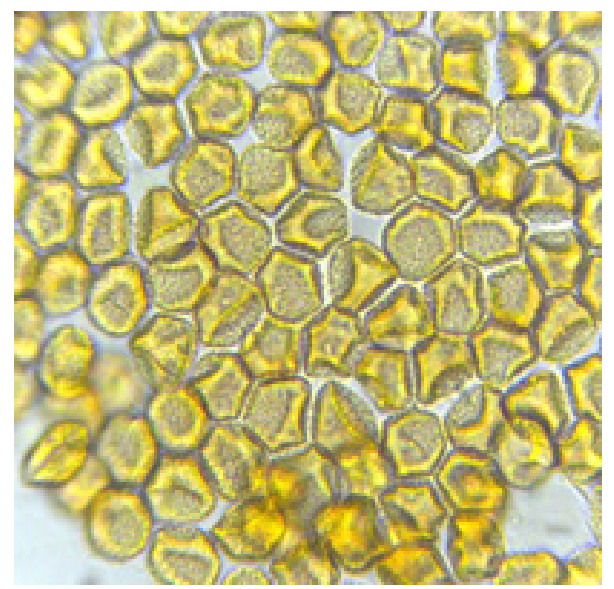

Figure 18 Hemitrichia montana (Morgan) T. Macbr. ${ }^{12}$

\section{Conclusion}

Hypothallus, Stalk, Columella, Pseudocolumella, Capillitium, Pseudocapillitium, Peridium, Cortex, Calyculus and Spores structures of mycomycetes have been explained with examples. In this study fruiting bodies structures of myxomycetes have presented.

\section{Funding}

None.

\section{Acknowledgements}

None.

\section{Conflicts of interest}

The author declares that there is no conflict of interest.

\section{References}

1. Baba H, Tamer AÜ. A study on the Myxomycetes in Manisa. The Herb Journal of Systematic Botany. 2007;14(2):179-196.

2. Ergül CC, Akgül H. Myxomycete diversity of Uludağ national park, Turkey. Mycotaxon. 2011;116(479):1-16.

3. Ergül CC, Akgül H, Oran RB. New records of Mycetozoa taxa from Turkey. Oxidation Communications. 2016;39(2):1615-1623.

4. Sesli E, Akata I, Denchev TT, et al. Myxomycetes in Turkey-a checklist. Mycobiota. 2016;6:1-20.

5. Ergul CC, Dulger B, Oran RB, et al. Myxomycetes of the western Black Sea Region of Turkey. Mycotaxon. 2005;96:362.

6. Gilbert HC, Martin GW. Myxomycetes found on the bark of living trees. University of Iowa, Iowa Stud Nat Hist. 1933;15(3):3-5.

7. Keller HW, Everhart SE, Kilgore CM. Chapter 1-The Myxomycetes: Introduction, Basic Biology, Life Cycles, Genetics, and Reproduction. Myxomycetes. 2017:1-40.

8. Baba H, Arslan Ç. Myxomycetes of North Amanos Mountains (Hatay/ Turkey). Biological Diversity and Conservation. 2017;10(3):88-95.

9. Stephenson SL, Stempen H. Myxomycetes: a handbook of slime molds. Timber Press; 1994.

10. Baba H, Zümre M, Gelen M. Biodiversity of Kuseyr Plateau Myxomycetes (Hatay-Turkey). Journal of Selcuk University, Natural and Applied Science. 2013;(Part 1):669-683.

11. Martin GW, Alexopoulos CJ. The Myxomycetes. Iowa City. University of Iowa press; 1969:560.

12. Baba H, Zumre M, Gelen M. An Investigation on North Adana (Turkey) Myxomycetes. Chiang Mai Journal of Science. 2016;43(1):54-67.

13. Baba H, Tamer AÜ. A New Myxomycetes Genus and Three Species Record for Turkish mycoflora. The Herb Journal of Systematic Botany. 2008;15(2):81-86.

14. Baba H. Some Mycetozoa (Myxomycetes) members from zorkun high plateau (Osmaniye). Anatolian Journal of Botany. 2017;1(2):37-40.

15. Baba H. A New Myxomycetes Genus and three species record for Turkey. International Journal of Botany. 2008;4:336-339.

16. Baba H. Diversity and Ecology of Myxomycetes in Antakya-Hatay (Turkey). The Journal of Fungus. 2012;3(1-2):5-11.

17. Baba H. The genus Physarum (Myxomycetes) checklist in Turkey. Biological Diversity and Conservation. 2015;8(3):20-24.

18. Baba H, Doğan Y. Investigation of Myxomycetes (Myxomycota) in South Amanos Mountains (Hatay-Turkey). Celal Bayar University Journal of Science. 2018;14(3):277-284. 